\title{
Synthesis of Bacillamide $\mathrm{C}$ analogues
}

\author{
Verónica R. Martínez ${ }^{\mathrm{a}}$, Gloria Serra ${ }^{\mathrm{a}}$, Danilo Davyt ${ }^{\star a}$ \\ ${ }^{a}$ Facultad de Química, Universidad de la República, General Flores 2124, Montevideo, Uruguay \\ *Corresponding author.Tel.: ++59829290290 Fax:++59829241906 e-mail: ddavyt@fq.edu.uy
}

Keyword: Bacillamide; Oxazole; Thiazole

\section{INTRODUCTION}

The Bacillamide A (1) recently isolated from the marine bacterium Bacillus sp. SY-1, is a compound with algaecide activity against the harmful dinoflagellate Cochlodinium polykrikoides. The bacillamide $C(2)$ isolated from a Bahamian hypersaline microbial mat, has not been tested for algicidal activity due to a lack of sufficient material. ${ }^{1}$ Different synthesis of this compound were described in literature. ${ }^{2}$ In this work we prepare the Bacillamide 2, by eight steps starting from L-alanine.

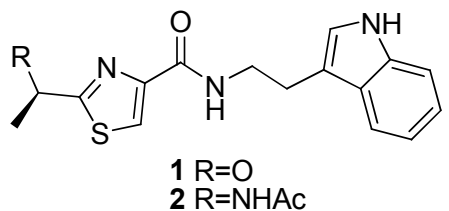

Figure 1. Bacillamides structure

\section{RESULTS AND DISCUSSION}

The thiazole ring has been subject of much interest in chemistry due to it presence in many naturally occurring compounds. Several methods for the preparation of thiazoline and thiazole ring have been reported. ${ }^{3}$<smiles>CC(C#N)NC(=O)OCC1C[13CH]2C[C@H]12</smiles>

3<smiles>CC(NC(C)C1CCCCC1)c1nc(C(=O)NCCc2c[nH]c3ccccc23)cs1</smiles>

2<smiles>CC(NC(=O)OCc1ccccc1)c1nc(C(=O)O)cs1</smiles>

4 a) Cys ethyl ester, $\mathrm{pH} 6$; b) $\mathrm{DBU}, \mathrm{BrCCl} 3$; c) $\mathrm{KOH}$, THF; g) tryptamine, ClCO2Et; h) Ac2O, Py
The N-Boc aminoacetonitrile 3 was prepared in three steps starting from L-alanine. Then thiazoline ring was obtained by addition of cysteine ethyl ester in $\mathrm{pH} 6$ phosphate buffer, the reaction mixture was stirred overnight at $60^{\circ} \mathrm{C}$. The thiazoline was oxidized to thiazole using bromotrichloromethane-DBU. Finally ester hydrolysis using $\mathrm{KOH}$ in THF afforded compound 4. ${ }^{4}$ The condensation between 4 and tryptamine gave the N-Boc bacillamide. Finally, 2 was obtained after Boc-deprotection and $\mathrm{N}$-acetylation.

In order to synthesize new analogues, we applied this methodology starting from different amino acids besides L-alanine, Figure 2 .

The preparation of analogues containing the oxazole ring, were prepared employing the methodology reported by Wipf. ${ }^{5}$<smiles>[R]NC([R])c1c[X]c(C(=O)NCCc2c[nH]c3ccccc23)n1</smiles>

Figure 2. Bacillamides analogues.

The bacillamide $\mathrm{C}$ and analogues containing oxazole ring were synthesized, nevertheless some steps of synthesis should be optimized for best performance, and then test their biological activities.

\section{REFERENCES}

${ }^{1}$ Socha, A. M.; Long, R. A. e Rowley, D. C. J. Nat. Prod. 2007, 70, 1793.

2 Li, D.; Yang H. S.; Cui Q.; Mao S. J. e Xu X. H. Chin. Chem. Lett. 2009, 20, 1195

${ }^{3}$ Gaumont, A.; Gulea,M.; Levillain, J. Chem. Rev. 2009, 109, 13711401

${ }^{4}$ Seiser, T.; Kamena, F.E., Cramer, N. Angew. Chem. Int. Ed. 2008, 47,

${ }^{6}$ Phillips, A. J.; Uto, Y.; Wipf, P; Reno, M. e Williams, D. R. Org. Lett., 2000, 2, 1165

Scheme 1. Synthesis of Bacillamide C 